\title{
PERAN NOTARIS/PPAT DALAM PEMBUATAN AKTA PEMBAGIAN HAK BERSAMA (APHB) TERHADAP PEMBAGIAN WARIS YANG BERBEDA AGAMA ATAS TANAH DAN BANGUNAN
}

\author{
Tatik Arjiati \\ Mahasiswa Program Magister (S2) Kenotariatan Fakultas Hukum Unissula \\ taty.arji88@ymail.com \\ Lathifah Hanim \\ Dosen Fakultas Hukum Unissula
}

\begin{abstract}
ABSTRAK
Notaris/PPAT adalah pejabat yang diberi kewenangan untuk membuat akta otentik yang dapat dipercaya. Pemisahan harta waris dilaksanakan dalam suatu akta dimuka seorang Notaris yang berupa Surat Keterangan Waris. Pembagian harta warisan bagi ahli waris dapat menjadi hak masing-masing pemegang hak bersama tersebut berdasarkan Akta Pembagian Hak Bersama yang dibuat oleh Pejabat Pembuat Akta Tanah (PPAT). Pewarisan dalam Islam menganal adanya keberadaan yang sama terkait agama pewaris dan ahli waris.

Permasalahan dalam penelitian ini: Bagaimana peran Notaris/PPAT dalam pembuatan APHB terhadap pembagian waris beda agama? Apakah kendala-kendala dan solusi terhadap pembuatan APHB terhadap pembagian waris beda agama? Bagaimana akibat hukum jika ada ahli waris yang berbeda agama yang tidak mau hadir menandatangani APHB dihadapan notaris?

Tujuan dari Penelitian ini adalah (1) Untuk menganalisis peran Notaris/PPAT terhadap pembuatan APHB pembagian waris beda agama. (2) Untuk menganalisis kendala-kendala dan solusi terhadap pembuatan APHB terhadap pembagian waris; dan (3) Untuk mengetahui akibat hukum jika ada ahli waris yang tidak mau hadir menandatangani APHB di depan Notaris.

Penelitian yang penulis lakukan yakni di Provinsi Jawa Tengah yaitu di Kota Semarang. Adapun metode penelitian yang digunakan dalam penelitian ini adalah metode pendekatan studi non doktrinal.

Hasil penelitian ini adalah: 1) Peran Notaris/PPAT adalah membuat Akta pernyataan ahli waris yang dibuat dalam bentuk tulisan yang ditandatangani oleh notaris/PPAT sebagai alat pembuktian yang sah. 2) Kendala dalam pembuatan APHB terhadap pembagian waris beda agama atas tanah dan bangunan adalah masyarakat pribumi masih berorientasi pada Hukum Adat yang berlaku umumnya. Solusi Kantor pertanahan lebih banyak melakukan sosialisasi peraturan kepada masyarakat. 3) Akibat hukum jika ada ahli waris yang berbeda agama yang tidak mau hadir menandatangani APHB dihadapan notaris adalah kedudukan akta Notaris dapat dibatalkan demi hukum, dan mempunyai kekuatan pembuktian sebagai akta dibawah tangan.
\end{abstract}

Kata kunci : Peran Notaris/PPAT, Akta Otentik, Pembagian Waris

\section{A. PENDAHULUAN}

\section{Latar Belakang}

Notaris/PPAT adalah salah satu lembaga yang disebutkan dalam Kitab Undang-Undang Hukum Perdata yang kewenangannya berhubungan erat dengan pembuatan akta otentik dan kewenangan lainnnya. Berangkat dari kebutuhan akan suatu alat pembuktian yang sempurna (volledig bewijs) sesuai dengan Burgelijke Wetboek (BW) atau Kitab Undang-Undang Hukum Perdata (KUHPerdata) dan Herzien Inlandsch Reglement (HIR) atau Hukum Acara Perdata Indonesia selain untuk kebenaran materiil, Notaris juga mempunyai peran dan tugas yang penting serta kedudukan yang terhormat. ${ }^{1}$

\footnotetext{
1 Andri Cahayadi, Peran Notaris Dalam Membantu Menyelesaikan Masalah Waris Melalui Pembuatan Keterangan Waris, Universitas Indonesia, Jakarta, 2011, hlm. 82
}

Proses pewarisan berupa tanah sering terjadi dalam kehidupan masyarakat, mengingat tingginya nilai ekonomis yang dimiliki oleh tanah tersebut. Hal demikian yang kerap kali memicu perselisihan (potensi sengketa) di masyarakat, bahkan di dalam lingkup kekeluargaan. Tidak sedikit anggota keluarga (para ahli waris) yang terlibat perselisihan karena pewarisan.

Akta Pembagian Hak Bersama merupakan salah satu dokumen yang dijadikan dasar untuk mengurus pendaftaran peralihan hak ke Kantor Pertanahan setempat. Apabila ahli waris hanya menyertakan Surat Keterangan Waris, maka hak atas tanah tersebut masih berstatus kepemilikan bersama-sama. Namun, jika ahli waris menyertakan Akta Pembagian Hak Bersama, maka hak atas tanah tersebut sudah bisa berstatus sebagai hak individu, tergantung dengan kesepakatan (isi) yang tercantum di dalam Akta Pembagian Hak Bersama tersebut. Pejabat Pembuat Akta Tanah merupakan pejabat yang berwenang membuat Akta Pembagian Hak Bersama. 
Berdasarkan Al-Qur'an dan Hadist, Peraturan Perundang-undangan, dan kesepakatan ulama' menjelaskan bahwa waris beda agama tidak diperbolehkan, tetapi pada praktiknya masih ada putusan hakim yang memberikan hak waris kepada seorang ahli waris non-muslim. Hukum kewarisan tidak dapat dipisahkan dari sistem kekeluargaan sebab hukum kewarisan merupakan bagian dari hukum kekeluargaan. Didalam suatu kekeluargaaan terjadi proses pewarisan atau disebut juga dengan turun waris.

\section{Rumusan Masalah}

a. Bagaimana peran Notaris/PPAT dalam pembuatan APHB terhadap pembagian waris beda agama atas tanah dan bangunan?

b. Apakah kendala-kendala dan solusi terhadap pembuatan APHB terhadap pembagian waris beda agama atas tanah dan bangunan?

c. Bagaimana akibat hukum jika ada ahli waris yang berbeda agama yang tidak mau hadir menandatangani APHB dihadapan notaris?

\section{B. PEMBAHASAN}

\section{Peran Notaris/PPAT Dalam Pembuatan APHB Terhadap Pembagian Waris Beda Agama Atas Tanah Dan Bangunan}

Pewarisan merupakan suatu proses beralihnya harta kekayaan seseorang kepada ahli warisnya yang terjadi hanya karena kematian. Oleh karena itu pewarisan baru akan terjadi jika terpenuhi 3 persyaratan, yaitu :

a. Ada seseorang yang meninggal dunia ;

b. Ada seseorang yang masih hidup sebagai ahli waris yang akan menerima sejumlah harta peninggalan pada saat pewaris meninggal dunia. Ahli waris atau para ahli waris harus ada pada saat pewaris meninggal dunia.Ketentuan ini tidak berarti mengurangi makna Pasal 2 B.W yaitu: "anak yang ada dalam kandungan seorang perempuan dianggap sebagai telah dilahirkan, bilamana kepentingan si anak menghendakinya:'.Apabila ia meninggal saat dilahirkan, ia dianggap tidak pernah ada. Dengan demikian berarti bayi dalam kandungan juga sudah diatur haknya oleh hukum sebagai ahli waris dan telah dianggap cakap untuk mewaris

c. Ada sejumlah harta kekayaan yang ditinggalkan pewaris.

Ahli waris menurut Pasal 171 huruf c Kompilasi Hukum Islam (KHI) menyatakan bahwa :

Ahli waris adalah orang yang pada saat meninggal dunia mempunyai hubungan darah atau hubungan perkawinan dengan pewaris, beragama Islam dan tidak terhalang oleh hukum untuk menjadi ahli waris.

Pengertian beragama Islam dalam hal ini adalah sebagaimana diatur dalam Pasal 172 Kompilasi Hukum Islam (KHI) yang menyatakan bahwa :
Ahli waris dipandang beragama islam dilihat dari Kartu Identitas atau pengakuan atau amalan atau kesaksian, sedangkan bagi bayi yang baru lahir atau anak yang belum dewasa, beragama menurut ayahnya atau lingkungannya.

Unsur agama yang dimaksud menurut ketentuan Pasal 171 huruf c Kompilasi Hukum Islam (KHI) adalah yang berhak menjadi ahli waris (yang beragama Islam) harus beragama Islam (seagama dengan pewaris). Sehingga dengan demikian apabila antara pewaris dengan ahli waris tidak seagama (biasanya ahli warisnya non-muslim), maka tidak saling mewaris atau bukan ahli waris dari pewaris yang beragama Islam.

Ditinjau sudut pandang Hukum Waris Islam, maka anak yang lahir dari perkawinan beda agama tidak mempunyai hak untuk mendapatkan harta waris apabila tidak seagama dengan pewaris yang dalam hal ini pewaris beragama Islam. Namun demikian apabila pewaris tidak beragama Islam (non-muslim), sedangkan ahli warisnya tidak seagama dengan pewaris (nonmuslim), maka tetap berhak mewaris. Hal tersebut didasarkan pada hubungan darah antara pewaris dengan ahli waris, sebagaimana diatur dalam ketentuan Pasal 832 KUH Perdata maupun Pasal 171 huruf c Kompilasi Hukum Islam (KHI).

Persyaratan administrasi dalam hal mewarisi wajib dilengkapi untuk ketertiban data admisnistrasi di Kantor Kelurahan dan Kecamatan. Surat Keterangan Waris ditandatangani oleh para ahli waris dengan 2 (dua) orang saksi, serta Lurah dan Camat setempat.

Surat Keterangan Waris bagi Warga Negara Indonesia golongan pribumi dapat diperoleh di Kantor Kelurahan/Kepala Desa, dan Kantor Kecamatan setempat, bagi warga negara Indonesia keturunan Tionghoa berupa Surat Keterangan Waris yang dibuat oleh seorang Notaris, sedangkan bagi Warga Negara Indonesia golongan Timur Asing dapat memperoleh di Balai Harta Peninggalan. Jadi di Indonesia belum ada keseragaman atau unifikasi mengenai Surat Keterangan Waris yang berlaku bagi seluruh Warga Negara Indonesia dan juga belum ada standar baku mengenai format Surat Keterangan Waris yang berlaku bagi golongan pribumi.

\section{Kendala-Kendala Dan Solusi Terhadap Pembuatan APHB Terhadap Pembagian Waris Beda Agama Atas Tanah Dan Bangunan}

Hambatan yang pernah dihadapi masyarakat dalam upaya pemenuhan syarat tanda bukti hak waris berupa surat keterangan waris untuk pribumi atau penduduk asli di kantor kelurahan dan kecamatan berdasarkan hasil wawancara adalah sebagai berikut ${ }^{2}$

\footnotetext{
${ }^{2}$ Agung Basuki, S.ST.MH., Wawancara, Kepala Seksi Peralihan, Pembebanan Hak dan PPAT BPN Kota Semarang. Pada tanggal 13 Februari 2017
} 


\begin{tabular}{|c|c|c|}
\hline No. & Hambatan-Hambatan & Solusi \\
\hline 1. & $\begin{array}{l}\text { Kendala Pembuatan APHB dari masyarakat adalah adanya } \\
\text { ketidaktahuan terkait: } \\
\text { 1. Peraturan-peraturan di bidang pertanahan serta prosedur } \\
\text { atau tata cara pembuatan surat keterangan waris. } \\
\text { 2. Kelengkapan syarat-syarat yang diperlukan dalam } \\
\text { pembuatan surat keterangan waris. } \\
\text { 3. Pentingnya sertipikat tanah sebagai alat bukti bila terjadi } \\
\text { sengketa kepemilikan tanah } \\
\text { 4. Adanya pengaruh adat yang kuat terkait pewarisan dapat } \\
\text { diperoleh secara turun temurun } \\
\text { 5. Banyak anggota masyarakat yang melakukan peralihan } \\
\text { hak atas tanah dengan cara dibawah tangan } \\
\text { 6. Adanya keengganan masyarakat untuk membuat akta } \\
\text { Otentik dihadapan Notaris atau Pejabat Pembuat Akta } \\
\text { Tanah (PPAT) karena adanya anggapan kerumitan dan } \\
\text { biaya. } \\
\text { 7. Proses permohonan pewarisan ke Menteri Hukum dan } \\
\text { Hak Asasi Manusia lewat Notaris/PPAT bagi masyarakat } \\
\text { Tionghoa. }\end{array}$ & $\begin{array}{l}\text { Upaya dari masyarakat berupa: } \\
\text { - Berkonsultasi dan meminta bantuan } \\
\text { kepada aparat pemerintah di kelurahan } \\
\text { atau kecamatan setempat, menanyakan } \\
\text { kepada tetangga, saudara, atau teman yang } \\
\text { pernah membuat surat keterangan waris } \\
\text { dan pernah melakukan pendaftaran tanah. } \\
\text { - Pemerintah perlu melakukan sosialisasi } \\
\text { kepada masyarakat tentang proses } \\
\text { peralihan hak katas tanah, sehingga dalam } \\
\text { peralihan ha katas tanah dan bagunan } \\
\text { melalui APHB masyarakat dapat } \\
\text { mengetahui prosedur seerta syarat-syarat } \\
\text { proses APHB yang beda agama. }\end{array}$ \\
\hline 2. & $\begin{array}{l}\text { Kendala Pejabat Pembuat Akta Tanah } \\
\text { Kendala budaya/kultur: } \\
\text { 1. Kantor Pertanahan terlalu kaku dalam menerapkan } \\
\text { kelengkapan persyaratan. } \\
\text { 2. Kebiasaan Pejabat Pembuat Akta dalam pembuatan } \\
\text { perjanjian hak bersama berupa tanah hanya melibatkan } \\
\text { dua orang saksi dari silsilah pewaris, tidak melibatkan } \\
\text { pegawai. } \\
\text { 3. Kurangnya kesadaran hukum ahli waris dalam } \\
\text { melengkapi persyaratan proses pembagian hak bersama. }\end{array}$ & $\begin{array}{l}\text { Upaya Aparatur Pemerintahan } \\
\text { Kantor Pertanahan berupa: } \\
\text { Memberikan informasi mengenai prosedur } \\
\text { dan tata cara pendaftaran serta dokumen } \\
\text { dokumen yang belum lengkap kepada } \\
\text { pemohon. }\end{array}$ \\
\hline 3. & $\begin{array}{l}\text { Kendala Substansi Hukum berupa: } \\
\text { 1. Belum ada aturan mengenai standar baku (format) Surat } \\
\text { Keterangan Waris yang berlaku bagi golongan pribumi. } \\
\text { 2. Aturan mengenai keharusan pencantuman tanda tangan } \\
\text { asli para ahli waris dalam pembuatan Surat Keterangan } \\
\text { Waris dan Akta Pembagian hak Bersama. } \\
\text { 3. Aturan mengenai sistem pecah sempurna yang } \\
\text { membutuhkan waktu cukup lama dan pengenaan biaya } \\
\text { perpajakan yang cukup banyak. }\end{array}$ & $\begin{array}{l}\text { Kantor Kecamatan dan Kelurahan berupa: } \\
\text { Membantu memberikan informasi dan } \\
\text { melengkapi dokumen-dokumen } \\
\text { diperlukan oleh para pemohon, serta } \\
\text { memantau jalannya proses di kantor } \\
\text { pertanahan agar cepat selesai. }\end{array}$ \\
\hline
\end{tabular}

\section{Akibat Hukum Jika Ada Ahli Waris Yang Berbeda Agama Yang Tidak Hadir Menandatangani APHB Dihadapan Notaris/ PPAT}

Mengenai tujuan dari tanda tangan dalam akta Notaris, Arianto Mukti Wibowo berpendapat bahwa tujuan sebuah tanda tangan adalah untuk memberikan ciri atau mengindividualisir suatu akta. ${ }^{3}$ Menurut Sudikno Mertokusumo, Akta adalah surat sebagai alat bukti yang diberi tanda tangan, yang berisi tentang peristiwa yang menjadi dasar suatu hak atau perikatan, yang sejak semula dibuat dengan sengaja untuk tujuan

\footnotetext{
3 Arianto Mukti Wibowo, Dalam Naskah Akademik RUU Tanda Tangan Elektronik dan Transaksi Elektronik, 2001, hlm. 66
}

pembuktian. Jadi untuk dapat digolongkan dalam pengertian akta maka surat harus ditanda tangani.

Dengan demikian dengan alasan tertentu jika akta yang berbeda sebagaimana tersebut di atas, maka kedudukan akta Notaris :

a. dapat dibatalkan;

b. batal demi hukum;

c. mempunyai kekuatan pembuktian sebagai akta dibawah tangan;

d. dibatalkan oleh para pihak sendiri.

Otensitas dari akta Notaris bersumber dari Pasal 1 ayat (1) Undang-Undang Jabatan Notaris No. 2 Tahun 2014, yaitu Notaris dijadikan sebagai pejabat umum, sehingga akta yang dibuat oleh Notaris dalam kedudukannya tersebut memperoleh sifat akta otentik. 


\section{PENUTUP}

\section{Kesimpulan}

a. Peran Notaris/PPAT dalam pembuatan APHB terhadap pembagian waris beda agama atas tanah dan bangunan yaitu Notaris adalah pejabat umum yang berwenang untuk membuat akta otentik sejauh pembuatan akta otentik tertentu tidak dikhususkan bagi pejabat umum lainnya. Yang dapat dilakukan notaris adalah dengan membuat Akta pernyataan ahli waris. Pernyataan ahli waris dibuat dalam bentuk tulisan yang ditandatangani oleh notaris karena dibuat di hadapan notaris, dengan surat tanda bukti hak waris yang dapat menjadi alat pembuktian yang sah seorang ahli waris untuk dapat melakukan pendaftaran hak milik atas tanah adalah Surat Tanda Bukti Sebagai Ahli Waris atau Surat Keterangan Waris;

b. Kendala-kendala dan solusi terhadap pembuatan APHB terhadap pembagian waris beda agama atas tanah dan bangunan, yaitu warga Negara Indonesia Pribumi Muslim ingin membagi harta peninggalan orangtuanya dengan mempergunakan Surat Keterangan Waris yang diterbitkan Camat. Camat jelas tidak akan menerbitkan Surat Keterangan Waris tersebut meskipun mengetahui betul bahwa warganya tersebut (ahli waris) adalah seorang muslim, sehingga Camat akan memberikan Surat Keterangan Waris yang menyatakan hanya istri dan kedua anak si pewaris saja yang berhak sebagai ahli waris. Orientasi hanya didasarkan Hukum Adat yang berlaku umum.

c. Akibat hukum jika ada ahli waris yang berbeda agama yang tidak mau hadir menandatangani APHB dihadapan notaris yang selanjutnya diajukan permohonan ke Kementerian Hukum dan Asasi Manusia. Dengan demikian dengan alasan tertentu jika Akibat hukum jika ada ahli waris yang berbeda agama yang tidak mau hadir menandatangani APHB dihadapan notaris, maka kedudukan akta Notaris :

1) dapat dibatalkan;

2) batal demi hukum;

3) mempunyai kekuatan pembuktian sebagai akta dibawah tangan;

4) dibatalkan oleh para pihak sendiri.

\section{Saran}

a. Notaris/Pejabat Pembuat Akta Tanah disarankan untuk lebih menguasai hukum pewarisan secara adat, lebih professional dalam melaksanakan tugas jabatannya. b. Diharapkan agar pemerintah khususnya Badan Pertanahan Nasional melalui Kantor-Kantor Pertanahan yang ada diseluruh Indonesia untuk lebih mensosialisasikan Peraturan-Peraturan pertanahan khususnya Tentang Pendaftaran Tanah

\section{DAFTAR PUSTAKA}

\section{A. Buku-Buku}

Abdul Ghofur Anshori, 2009, Lembaga Kenotariatan Indonesia Perspektif Hukum dan Etika, UII Press, Yogyakarta.

Abdul Qadim Zallum, 2004, Al-Amwal, Darul Ummah, Beirut.

Abdulkadir Muhammad, 1990, Hukum Waris, Gema Insani Pers. Bandung.

Abdurrahman Al-Maliki, 1963, As-Siyasah AlIqtishadiyah al-Mutsla, Hizbut Tahrir, t.tp.

Ahlan Sjarif, Surini dan Nurul Elmiyah, 2005, Hukum kewarisan $B W$ Jakarta.

\section{B. Peraturan Perundang-Undangan}

Peraturan perundangan lainnya yang berkaitan dengan materi penulisan hukum ini.

Fatwa Munas VII Majelis Ulama Indonesia (MUI) Nomor : 5/MUNAS VII/9/2005 tentang Kewarisan Beda Agama, yang ditetapkan di Jakarta pada tanggal 28 Juli.

\section{Jurnal/Artikel Ilmiah}

Arianto Mukti Wibowo, 2001, Naskah Akademik RUU Tanda Tangan Elektronik dan Transaksi Elektronik.

Soetandyo Wignjosoebroto, 2010, Silabus Metode Penelitian Hukum, Program Pascasarjana Universitas Airlangga, Surabaya.

\section{Internet}

http:// www.ajiehoesodo.com.

http://kbbi.web.id/notaris. 